Original

\title{
Clinicopathologic and Morphologic Analysis of the Adrenal Gland in Pomeranians with Non-IIIness Alopecia
}

\author{
全身症状を伴わない脱毛症を呈したポメラニアンにおける副腎の \\ 臨床病理学的および形態学的検討
}

\author{
Kumiko Shibata $^{1 *}$, Hiroshi Koie ${ }^{2)}$, Masahiko Nagata ${ }^{1)}$ \\ ${ }^{1)}$ Animal Dermatology Center, ASC, ${ }^{2)}$ College of Bioresource Sciences, Nihon University

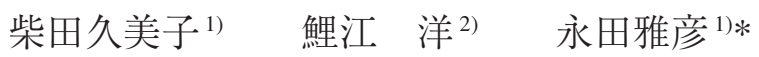 \\ ${ }^{1)} \operatorname{ASC}$ どうぶつ皮虐病センター, ${ }^{2)}$ 日本大学生物資源科学部
}

\begin{abstract}
We performed MRI scanning of the adrenal glands together with both clinicopathologic analysis and a skin biopsy in Pomeranians with non-illness, generalized alopecia. Fifty-one Pomeranians with the alopecia were included in this study, all of which had a brachycephalic type. Laboratory tests carried out on selected cases revealed slight elevations of several tests PCV, ALT, AST, ALP, and blood glucose, a slightly exaggerated response to ACTH stimulation test, and in some cases, inadequate suppression against low-dose dexamethasone. All animals showed a normal response to TSH administration. All 18 dogs on which we performed skin biopsies showed mild epidermal thinning, hyperkeratosis, follicular atrophy, and thinning of the subcutaneous adipose tissue. MRI scanning was performed in 14 of the affected dogs and 3 healthy control Pomeranians. Median length, width, and thickness of the adrenal gland in affected dogs were not different from those in control dogs, and no abnormality of the pituitary gland was found. Based on these findings, it is considered that abnormal adrenal steroidogenesis associated with adrenal hyperplasia is not an acceptable pathogenesis of this condition. It is hypothesized that the affected dogs seem to have a breed-and/or family-specific, physiological hormonal constitution that may lead to alopecia, rather than suffering from a functional anomaly of the adrenal gland.
\end{abstract}

Key words: alopecia, dog, MRI

要 約: 全身症状を伴わない沉発性脱毛症のポメラニアンに対して, 臨床病理学的および皮膚病理 組織学的検討と共に副腎のMRI検查を実施した。罹患例51例を本試験に供したが，全例が短頭種型 であった。諸検査を施行し，一部の症例でPCV，ALT，AST，ALP，血糖の軽度上昇，ACTH負荷試 験による軽度の過反応，低用量デキサメタゾン抑制試験における抑制障害がみられた。TSH刺激試 験に異常はみられなかった。皮膚病理組織学的検査施行 18 例すべてで軽度の表皮萎縮，角質肥厚， 毛包萎縮，皮下脂肪織の肥厚がみられた。MRI検査を罹患例 14 例と健常犬3例に施行したが，両者 に副腎の平均長径，短径，厚さの差異を認めず，下垂体異常もみられなかった。以上より，副腎過 形成を誘導する副腎ステロイド合成異常の病因的関与は否定的と考えられた。本症罹患犬は，先天 的副腎機能的異常よりも，全身症状を発症しない脱毛症を呈す種もしくは家系特異的な生理学的木 ルモン素因を有していると推察された。

キーワード：脱毛症, 犬, MRI

(Jpn J Vet Dermatol 2005, 11 (3): 115-120)

*Correspondence to: Kumiko Shibata (Animal Dermatology Center, ASC) 1-3-2 Jindaijihigashi Chofu, Tokyo 182-0012, Japan TEL +81-424-80-9342 FAX +81-424-41-6095 E-mail: shibata@gc4.so-net.ne.jp

*連絡先：柴田久美子（ASC どうぶつ皮膚病センター） = 182-0012 東京都調布市深大寺東町 1-3-2 


\section{INTRODUCTION}

Siege $\mathrm{l}^{11)}$ coined the term "Pseudo-Cushing's Syndrome" for idiopathic non-illness, generalized alopecia, which is similar to Cushing's syndrome in dogs. The syndrome occurs most commonly at 1 to 2 years of age, especially in male Pomeranians with no remarkable abnormalities in hemogram, serum chemistry analysis, or urinalysis, ${ }^{6,99}$. Some veterinary dermatologists call this phenomenon alopecia $X$, since the etiology remains unknown ${ }^{1,8)}$. In the 1990s, it was speculated that a deficiency of 21hydroxylase, an enzyme involved in adrenal steroidogenesis, was involved and this condition gave rise to the name congenital adrenal hyperplasia-like syndrome $^{7}$. It is suspected that an excess of sex hormone is due to the loss of cortisol negative-feedback regulation of ACTH secretion, resulting in a chronic excess of ACTH leading the enlarged adrenal glands. To date, however, there have been no morphologic studies of the adrenal gland in dogs with the alopecia, even though it is considered that abnormal adrenal steroidogenesis could be involved in the pathogenesis ${ }^{1)}$.

The purpose of this study is to evaluate morphologic verification of adrenal hyperplasia in Pomeranians with alopecia. We performed magnetic resonance imaging (MRI) scanning of the adrenal glands together with both a clinicopathologic analysis and a skin biopsy in the dogs.

\section{MATERIALS AND METHODS}

\section{Cases}

Fifty-one Pomeranians clinically diagnosed with the alopecia were included in this study. All cases were referred with a history of chronic, symmetrical alopecia, especially in the neck, trunk, caudal thigh, and tail, without any systemic signs (Fig. 1A).

Of the 51 dogs, 31 (60.8\%) were intact males, 7 (13.7\%) were castrated males, $9(17.6 \%)$ were intact females, and $4(7.8 \%)$ were spayed females. Their ages varied from 1 to 10 years, with a mean age of 4.3 years, and the mean age at which their owners noted a hair-coat abnormality was 3.1 years. Interestingly, all affected Pomeranians showed a brachycephalic face, which is characterized by a shorter length of the nose bridge compared with control dogs (Fig. 1B).
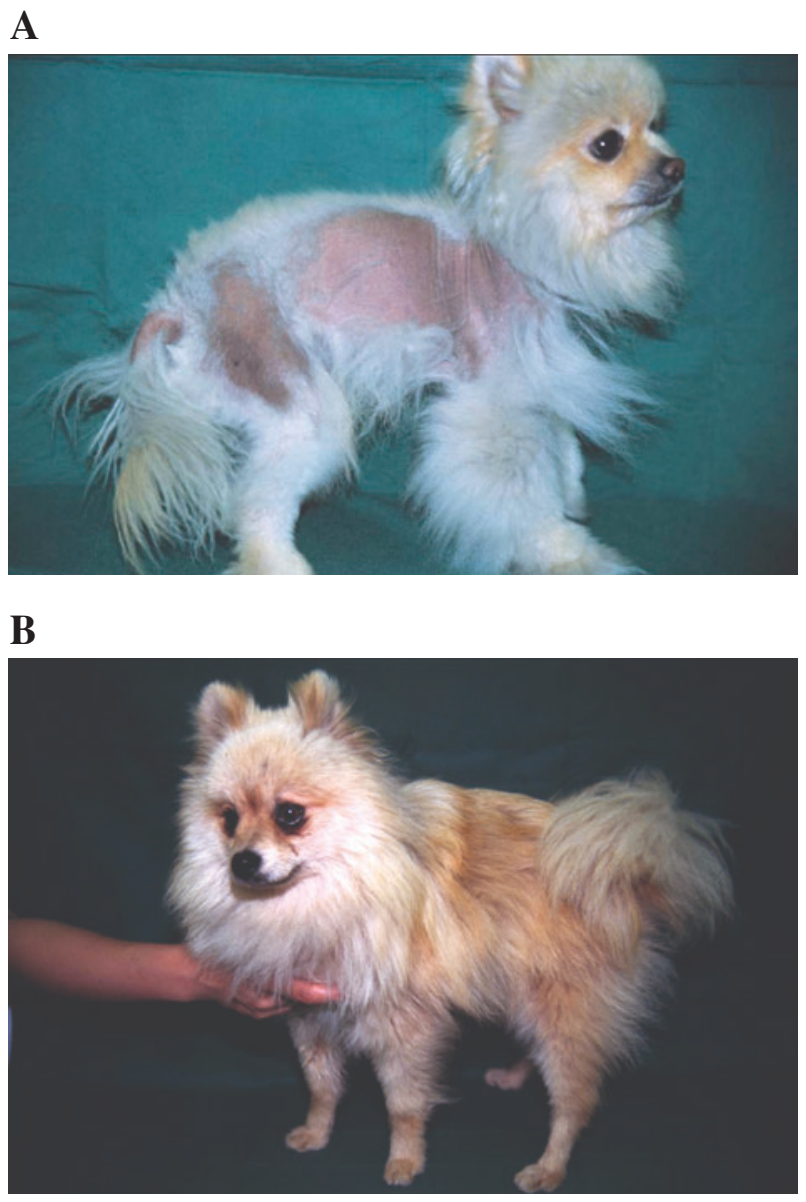

Fig. 1. Clinical features of affected Pomeranians. Note symmetric alopecia except for the face and distal extremities, and short nose-bridge (A), compared with control dogs (B).

\section{Clinicopathologic analysis}

Several laboratory tests were carried out on selected cases; hemograms including red blood cells, hemoglobin, packed cell volume (PCV), white blood cells, and platelet counts in 35 cases, and serum chemistry analysis including alanine aminotransferase (ALT), aspatate aminotransferase (AST), alkaline phosphatase (ALP), blood urea nitrogen, creatinine, blood glucose, cholesterol, total protein, albumin, globulin, calcium, phosphate, sodium, potassium, and chlorine in 41 cases. In addition, we performed an adrenocorticotropic hormone (ACTH) stimulation test in 19 cases, a low-dose dexamethasone (LD) suppression test in 19, and a thyroid-stimulating hormone (TSH) stimulation test in 20, hormonal functional tests were performed using standard procedures $^{3)}$. In the ACTH stimulation test, less than 22 $\mu \mathrm{g} / \mathrm{dl}$ of cortisol values at the $1 \mathrm{st}$ hour were considered normal. In the LD suppression test, less than $1.4 \mu \mathrm{g} / \mathrm{dl}$ of 


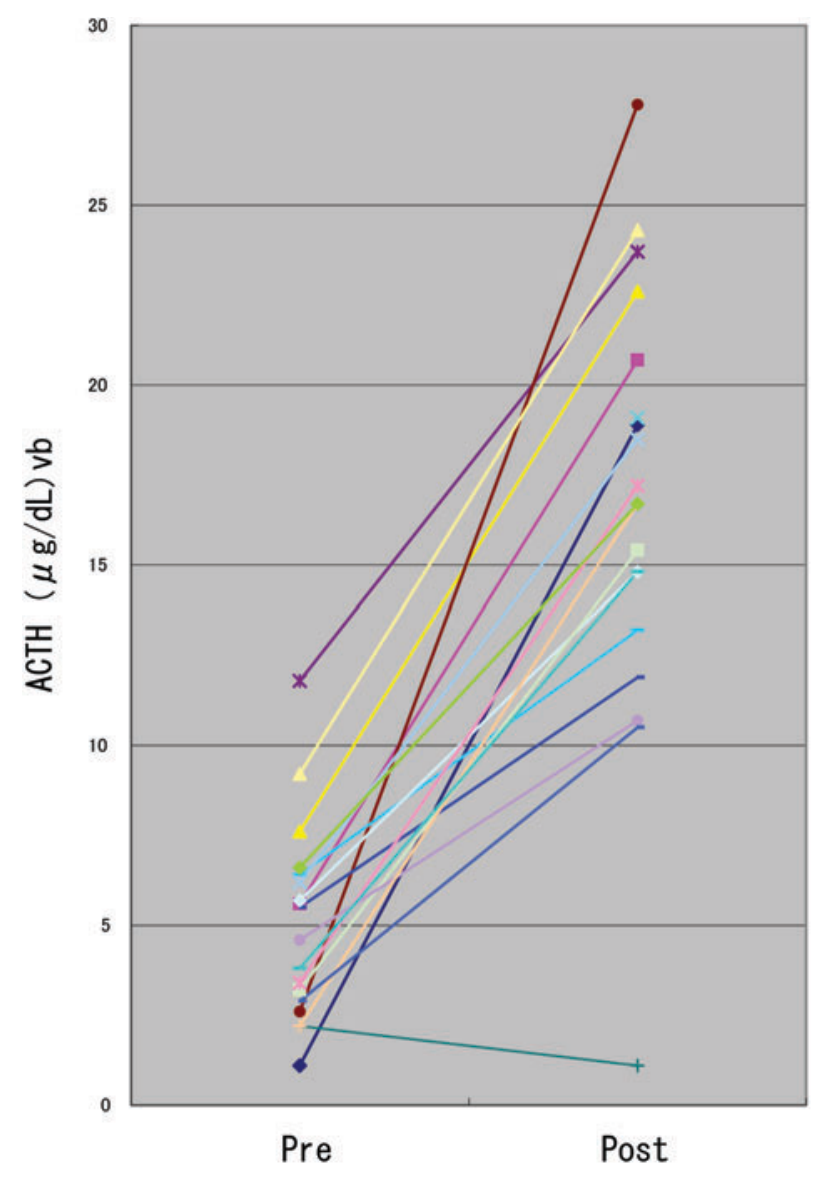

Fig. 2. Results of ACTH stimulation tests in affected dogs. Four of 19 cases $(21 \%)$ had a slightly exaggerated response.

cortisol value at the 8 th hour were also considered normal, as well as TSH stimulation tests showing less than 3.0 $\mu \mathrm{g} / \mathrm{dl}$ of T4 value or twice T4 value compared with a baseline level at the 6th hour.

\section{Histopathology of the skin}

Skin biopsies were performed for the alopecia in 18 cases. Tissue specimens were taken with 6-mm punch biopsies, fixed in neutral buffered $10 \%$ formalin, and processed using standard procedures.

\section{MRI Scanning}

MRI (Flexart: MRT-50GP, Toshiba, Tokyo, Japan) was performed for 14 Pomeranians with the alopecia and 3 healthy controls the dogs were positioned in sternal recumbency. Sagittal, horizontal, and transversa sections were obtained through the adrenal glands and the pituitary fossa. The Images were obtained of T1 \& T2- weighted, 4-mm contiguous sections. Size of the adrenal glands was estimated by measuring the maximum length, width,

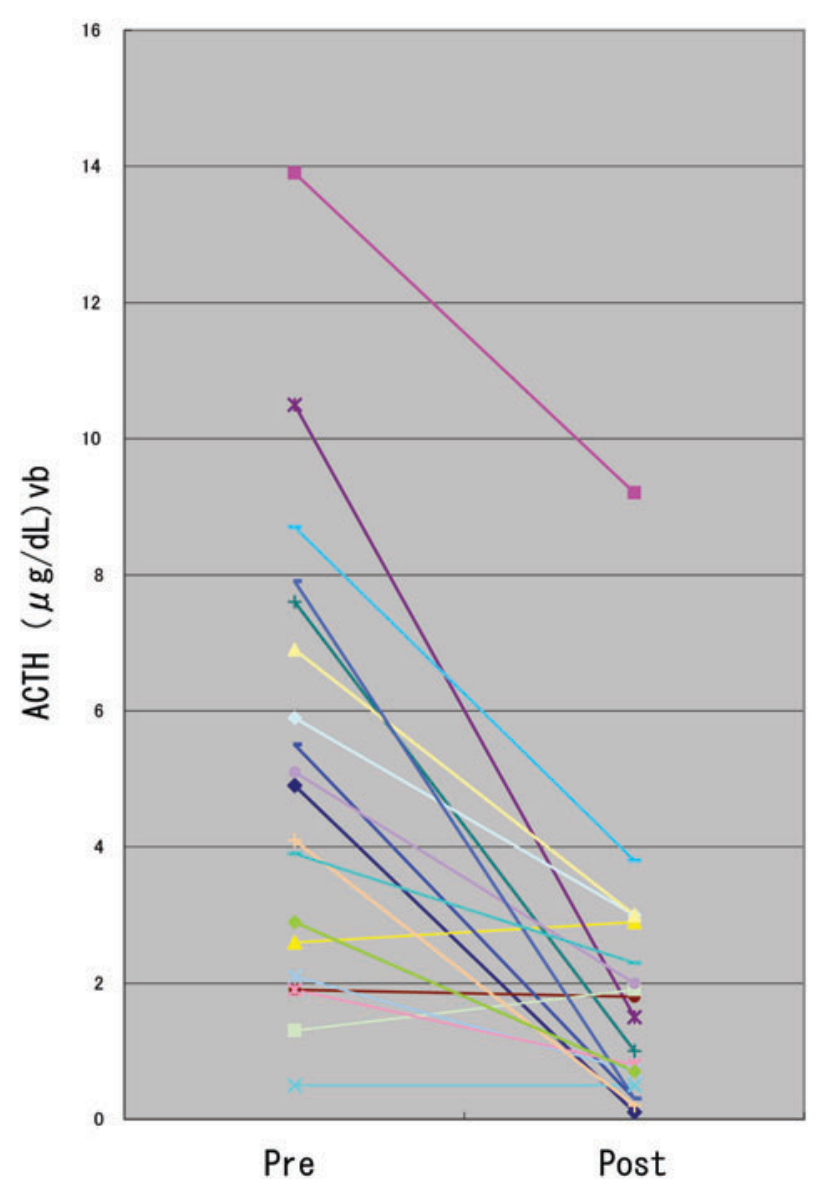

Fig. 3. Results of LDD suppression tests in affected dogs. Ten of 19 cases $(53 \%)$ had inadequate suppression.

and thickness, with particular attention also given to the presence or absence of a pituitary mass.

\section{RESULTS}

\section{Clinicopathologic analysis}

Hemograms revealed a slightly elevated PCV (median 57 , range $56-58)$ in 6 of $35 \mathrm{dogs}(17 \%)$. In serum chemistry analysis, the most common findings were a mild elevation of ALT (median $190 \mathrm{U} / 1$, range 134-299 U/1) in 15 of 40 cases (38\%), AST (median $59 \mathrm{U} / 1$, range 44-87 $\mathrm{U} / \mathrm{l})$ in 7 of 20 (35\%), ALP (median $510 \mathrm{U} / \mathrm{l}$, range 258$1336 \mathrm{U} / \mathrm{l}$ ) in 13 of 40 (32\%), and blood glucose (median $134 \mathrm{mg} / \mathrm{dl}$, range $127-149 \mathrm{mg} / \mathrm{dl})$ in 12 of 34 (35\%). The remaining tests showed no abnormalities. Figures 2 and 3 showed results of the hormonal functional tests. Four of 19 cases $(21 \%)$ had a slightly exaggerated response to the ACTH stimulation test (median $24.6 \mu \mathrm{g} / \mathrm{dl}$, range $22.6-27.8 \mu \mathrm{g} / \mathrm{dl}$ ), and 10 of $19(53 \%)$ showed inadequate suppression in the LD suppression tests (median $3.1 \mu \mathrm{g}$ / 


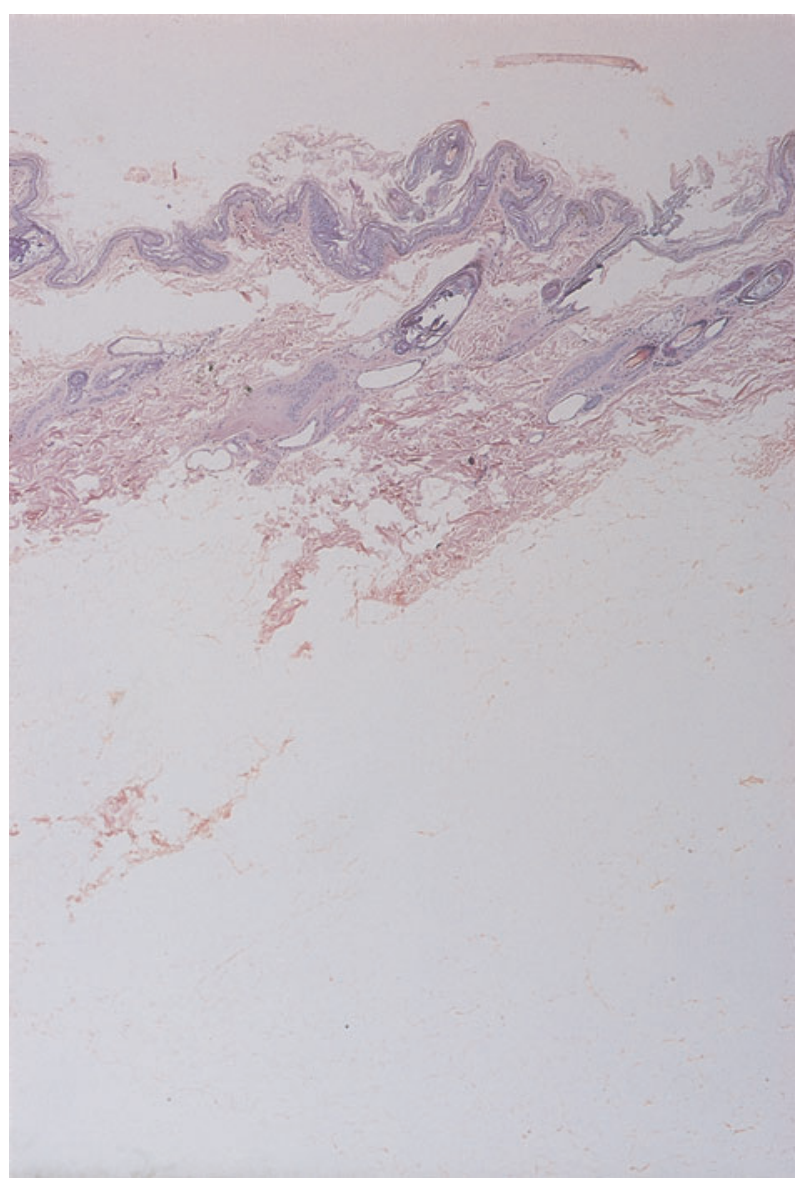

Fig. 4. Histopathologic features of the skin. Note mild epidermal thinning, hyperkeratosis, and follicular atrophy. In addition, subcutaneous adipose tissue was thicker than in the dermis.

dl, range 1.5-9.2 $\mu \mathrm{g} / \mathrm{dl})$. All cases had a normal response to TSH administration.

\section{Skin histopathology}

In all cases, histopathologic findings revealed mild epidermal thinning, hyperkeratosis, and follicular atrophy consistent with the telogen stage. In addition, the subcutaneous adipose tissue was thicker than that in the dermis (Fig. 4).

\section{MRI Scanning (Fig. 5 and Table 1)}

The left adrenal gland was clearly visible, whereas it was difficult to find the right adrenal gland due to an anatomical overlap by the caudal vena cava. The median length (13 mm-left, $12 \mathrm{~mm}$-right), width (4 mm-left, 4 mm-right), and thickness (5 mm-left, $5 \mathrm{~mm}$-right) of the adrenal gland in the dogs with the alopecia were very similar to the median length (13 mm-left, $12 \mathrm{~mm}$-right),

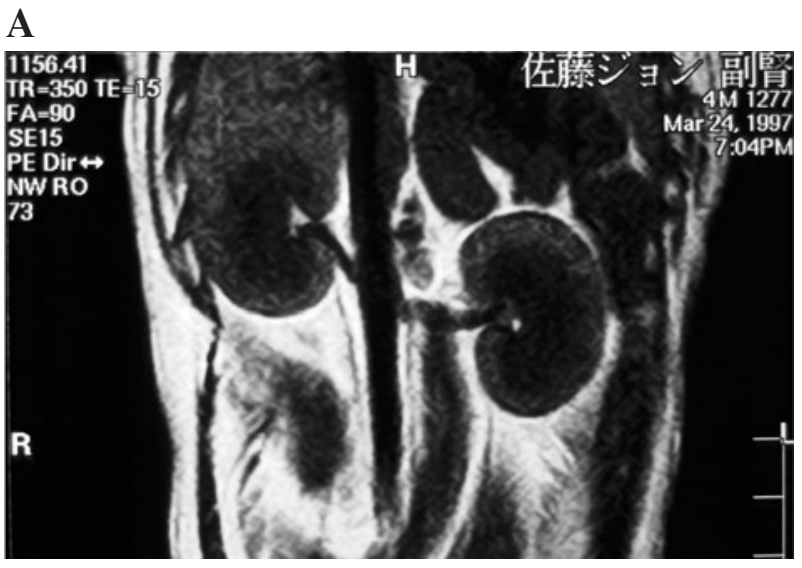

B

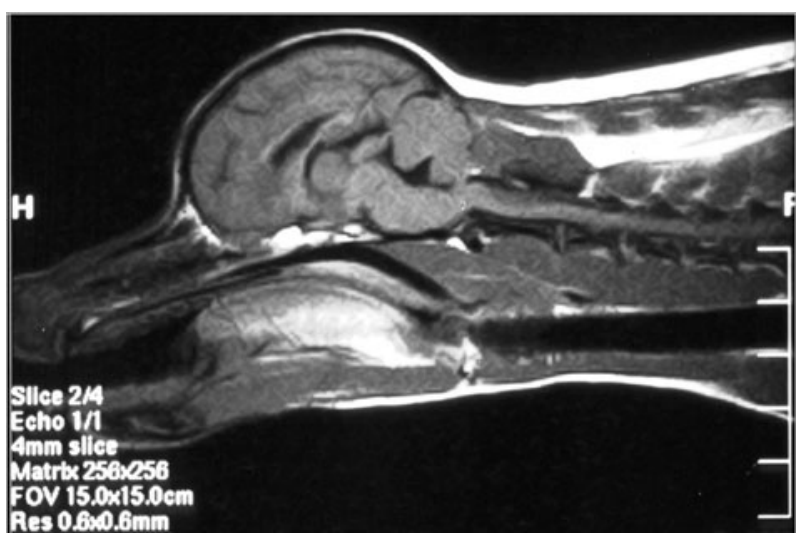

Fig. 5. MRI scanning of the adrenal (A) and pituitary gland (B). There are no morphologic abnormalities.

width (4 mm-left, $5 \mathrm{~mm}$-right), and thickness (6 mm-left, $6 \mathrm{~mm}$-right) in control dogs. In addition, no cases showed any mass corresponding to hyperplasia or a tumor of the pituitary gland.

\section{DISCUSSION}

In this study, adrenal hyperplasia was not detected morphologically in Pomeranians with alopecia. Congenital adrenal hyperplasia is an endocrinologic disorder recognized in human neonates, and takes two forms: a simple virilizing or a salt-wasting form ${ }^{5}$. Female patients are usually virilized, whereas affected males are normal in appearance ${ }^{5)}$. About two thirds of patients have mineralocorticoid deficiency, and the salt-wasting form results in hypoaldosteronism ${ }^{5}$. The present Pomeranian alopecia was male-predisposed, and the dogs showed no systemic signs, even though increases in 17 hydroxyprogesterone and cortisol production have been suggested ${ }^{1,7)}$. A recent genetic study showed that no 
Table 1. MRI measurements of adrenal glands in 14 Pomeranians with alopecia and in 3 healthy controls

\begin{tabular}{ccccccc}
\hline \multirow{2}{*}{ Cases } & \multicolumn{3}{c}{ Left adrenal gland (mm) } & \multicolumn{3}{c}{ Right adrenal gland (mm) } \\
& length & width & thickness & length & width & thickness \\
\hline 1 & 12 & 4 & 6 & 13 & 4 & 6 \\
2 & 11 & 4 & 5 & 13 & 4 & 4 \\
3 & 10 & 4 & 6 & 12 & 6 & - \\
4 & 14 & 4 & 5 & 12 & - & - \\
5 & 14 & 4 & 6 & - & - & - \\
6 & 13 & 4 & 5 & - & - & - \\
7 & 11 & 4 & 5 & - & - & - \\
8 & 11 & 6 & - & 10 & 4 & 6 \\
9 & 13 & 5 & - & 9 & 3 & - \\
10 & 13 & 3 & - & 9 & 4 & - \\
11 & 13 & 4 & - & - & - & - \\
12 & 13 & 3 & - & - & - & - \\
13 & 12 & 6 & - & - & - & - \\
14 & 16 & - & - & 14 & - & - \\
\hline Control dogs & 11 & 3 & 6 & 12 & 5 & - \\
1 & 14 & 4 & - & - & - & 6 \\
2 & 14 & 4 & - & - & - & - \\
3 & 14 & & & & &
\end{tabular}

-; Not visible.

mutation of the 21-hydroxylase genes was found in the affected Pomeranians ${ }^{12)}$. Based on these findings, abnormal adrenal steroidogenesis associated with adrenal hyperplasia is not an acceptable pathogenesis of this condition. Some investigators have postulated that this is a breed-associated mild form, or a variant of pituitarydependent hyperadrenocorticism ${ }^{1)}$. However, it should be emphasized that these dogs displayed only aesthetic problems, that start just after adolescence without any metabolic disturbance. In this study, all affected Pomeranians showed characteristic facial shape along with a slightly exaggerated response to ACTH stimulation test and, in some cases, inadequate suppression upon undergoing LD suppression tests. Thus, it is hypothesized that the dogs seemed to have a breed- and/or familyspecific, physiological hormonal constitution, which might lead to non-illness alopecia and the above characteristic facial structure rather than suffering from a functional anomaly of the adrenal gland.

As for its dermatological aspects, the distribution of the alopecia is restricted to specific areas such as the cervix, trunk, tail, perineal area, and caudal thigh, but the face and distal extremities are always spared ${ }^{9)}$. In addition, hair re-growth at injured sites (e.g. biopsy, trauma, and dermatitis) is one of common features in such $\operatorname{dog} s^{10)}$. These clinical characteristics suggest that a local defect in the hair growth cycle could be involved in the pathogenesis, and that the alopecia of Pomeranians might involve a similar physiologic process to that in human androgenic alopecia, which is a genetically predisposed, male-predominant, early-life onset, and a non lifethreatening follicular dysfunction ${ }^{2,4)}$. Further investigations will be needed.

\section{ACKNOWLEDGMENTS}

We are grateful to the referring veterinarians for enabling us to investigate these cases, and to Professor Ryoji Tsuboi of the Department of Dermatology, Tokyo Medical University for reviewing this paper. The Japan Forum on Small Animal Clinical Nutrition funded this project.

\section{REFERENCES}

1) Cerundolo, R., Lloyd, D.H., Persechino, A., Evans, 
H. and Cauvin, A. 2004. Treatment of canine Alopecia X with trilostane. Vet. Dermatol. 15: 285293.

2) Dawber, R.P.R., de Berker, D. and Wojnarowska, F. 1998. pp. 2903-2909. In: Rook/Wilkinson/Ebling Textbook of Dermatology, 6th ed. (Champion, R.H., et al. ed.) Blackwell Scientific Ltd., Oxford.

3) Feldman, E.C. and Nelson, R.W. 2004. pp. 86-357. In: Canine and Feline Endocrinology and Reproduction, 3rd ed. W.B. Saunders., Philadelphia.

4) Olsen, E.A. 1999. pp. 739-751. In: Fitzpatrick's Dermatology in General Medicine (Freedberg, I.M., et al. ed. 5th ed. McGraw-Hill Co., New York.

5) Orth, D.N., Kovacs, W.J. and Debold, C.R. 1992. pp. 489-620. In: Williams Textbook of Endocrinology, 8th ed. (Wilson, J.D., Foster, D.W., ed.) W.B. Saunders, Philadelphia.

6) Parker, W.M. and Scott, D.W. 1980. Growth hormone responsive alopecia in the mature dog: A discussion of 13 cases. J. Am. Anim. Hosp. Assoc. 16: 824-828.

7) Schmeitzel, L.P. and Lothrop, Jr., C.D. 1990. Hormonal abnormalities in Pomeranians with normal coat and in Pomeranians with growth hormoneresponsive dermatosis. J. Am. Vet. Med. Assoc. 197: 1333-1341.

8) Schmeitzel, L.P., Lothrop, C.D., Jr. and Rosenkrantz, W.S. 1995. pp. 600-604. In: Kirk's Current Veterinary Therapy XII. (Bonagura, J.D., ed.) W.B. Saunders, Philadelphia.

9) Scott, D.W., Miller, W.H., Jr. and Griffin, C.E. 2001. pp. 822-851. In: Muller and Kirk's Small Animal Dermatology, 6th ed. W.B. Saunders, Philadelphia.

10) Shibata, K. and Nagata, M. 1999. Hair regrowth after generalized pyoderma and flea infestation in a Pomeranian with adrenal sex hormone imbalance. Jpn. J. Vet. Dermatol. 5: 17-20 (in Japanese).

11) Siegel, E.T. 1977. pp. 23-32. In: Endocrine Diseases of the Dog, Lea \& Febiger., Philadelphia.

12) Takada, K., Kitamura, H., Takiguchi, M., Saito, M. and Hashimoto, A. 2002. Cloning of canine 21hydroxylase gene and its polymorphic analysis as a candidate gene for congenital adrenal hyperplasialike syndrome in Pomeranians. Res. Vet. Sci. 73: 159163. 